\begin{tabular}{|l|l|l||}
\hline \multicolumn{2}{|c|}{ PublisherInfo } \\
\hline \hline PublisherName & $:$ & BioMed Central \\
\hline \hline PublisherLocation & $:$ & London \\
\hline \hline PublisherImprintName & $:$ & BioMed Central \\
\hline \hline
\end{tabular}

\title{
Power law governs gene expression
}

\begin{tabular}{|l|l|l||}
\hline \multicolumn{2}{|c|}{ ArticleInfo } \\
\hline \hline ArticleID & $:$ & 4921 \\
\hline \hline ArticleDOI & $:$ & $10.1186 /$ gb-spotlight-20040304-01 \\
\hline \hline ArticleCitationID & $:$ & spotlight-20040304-01 \\
\hline \hline ArticleSequenceNumber & $:$ & 273 \\
\hline \hline ArticleCategory & $:$ & Research news \\
\hline ArticleFirstPage & $:$ & 1 \\
\hline \hline ArticleLastPage & $:$ & 3 \\
\hline \hline & & RegistrationDate : 2004-3-4 \\
\hline ArticleHistory & $:$ & OnlineDate \\
\hline \hline ArticleCopyright & $:$ & BioMed Central Ltd2004-3-4 \\
\hline \hline ArticleGrants & $:$ & \\
\hline \hline ArticleContext & $:$ & 130594411 \\
\hline \hline
\end{tabular}


With an ever-increasing number of genomes available for analysis, there has been a shift in emphasis away from the study of single genes and a greater attempt to understand gene expression at the network or systems level. A report in the March 1 Proceedings of the National Academy of Sciences USA shows that power laws - a universal mathematical dynamic - govern the process.

Hiroki Ueda and colleagues at the Center for Developmental Biology describe the mathematical principle underlying observed levels of gene expression. They used information from public databases of whole genome sequences and from their own microarray analyses. Proportional dynamics, also known as 'rich-travel-more', showed that power law levels of gene expression were observed not only in different organisms, but also within discrete organs or at specific developmental times in the same organism (Proc Natl Acad Sci USA 2004, DOI:10.1073/pnas.0306244101).

The team examined how genes change their expression in different conditions and observed that highly expressed genes change more, while genes expressed infrequently change less. "It's proportional; the magnitude of change[s] are proportional to their expression levels," said Ueda. "I also found [that] proportional dynamics can reproduce the complex pattern of distribution in gene expression level called power law distribution."

Ueda said he was surprised to find Escherichia coli and humans are governed by the same simple mechanism. "I am glad to have found a simple and universal mechanism that exists in all systems of life," he told us.

Plotting the distribution of different gene expression levels against the expression hierarchy of those genes results in a straight line. "I unexpectedly found that distribution[s] of gene expression were heterogeneous and governed by the power law of minus 2 exponent," he told us in an e-mail.

Yutaka Suzuki, research scientist at the Institute of Medical Science Human Genome Center explained, "In every case, you can see the straight line in the scattering plot. The basic concept is that such a kind of law is conserved between cell types and organisms in many kinds of context."

Suzuki, who was not involved in the study, explained that it is the ratio of minus 2 that is conserved. "That's the universal observation, that's the point of this manuscript," he said.

Lada Adamic, a power law expert in the Information Dynamics Laboratory at Hewlett-Packard, told us that although she was not a biologist, she would almost expect this observation because these distributions are extremely common. "As long as you have like a multiplicative process - which is what this is, this proportional process - you're going to end up with a distribution like that," she said.

Adamic, who was not involved in the study, said that the same distribution was actually observed by Yule in 1913 when he was looking at the abundance of species in different genera. "So that's kind of like a biological thing," she said. "The problem with power laws is that people keep kind of rediscovering them." 
"I myself have heard that this behavior of a system is very universal, [but] this is the first groundwork for this kind of analysis as I believe it. For biological systems, this is a first, so in that sense at least I think this is significant," Suzuki said.

Ueda said that in the future, statistical analysis utilizing this 'proportional' dynamics would be useful for the analysis of microarray data in any organism. "Statistical analysis based on 'proportional' dynamics can be applied to the search for the significantly changed genes in two conditions," he said in an E-mail. "We are preparing the manuscript on this type of application."

\section{References}

1. Proceedings of the National Academy of Sciences USA, [http://www.pnas.org/]

2. Center for Developmental Biology, [http://www.cdb.riken.jp/en/]

3. Hunter P: The power of power laws The Scientist, 17:22, April 21, 2003., [http://www.thescientist.com/yr2003/apr/feature_030421.html]

4. Institute of Medical Science Human Genome Center, [http://www.hgc.ims.u-tokyo.ac.jp/]

5. Lada Adamic, [http://www.hpl.hp.com/personal/Lada_Adamic/] 